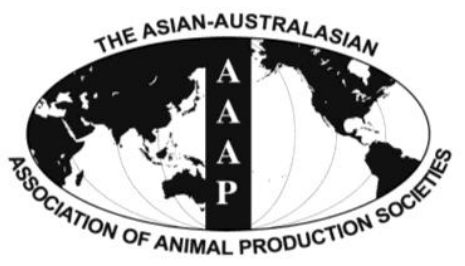

Asian-Aust. J. Anim. Sci.

Vol. 26, No. 4 : 579-587 April 2013

http://dx.doi.org/10.5713/ajas.2012.12612

www.ajas.info

pISSN 101 1-2367 elSSN 1976-5517

\title{
Effects of Supplementation of $\beta$-Mannanase in Corn-soybean Meal Diets on Performance and Nutrient Digestibility in Growing Pigs
}

\author{
J. N. Lv, Y. Q. Chen, X. J. Guo, X. S. Piao, Y. H. Cao and B. Dong* \\ Ministry of Agriculture Feed Industry Centre, State Key Laboratory of Animal Nutrition, \\ China Agricultural University, Beijing 100193, China
}

\begin{abstract}
A total of 288 crossbred (Duroc $\times$ Landrace $\times$ Yorkshire) growing pigs were used in two experiments to investigate the effects of adding $\beta$-mannanase to corn-soybean meal-based diets on pig performance and apparent total tract digestibility (ATTD). Both experiments lasted $28 \mathrm{~d}$ and were split into two phases namely 1 to 14 days (phase 1) and 15 to 28 days (phase 2). In Exp. 1,144 pigs weighing $23.60 \pm 1.59 \mathrm{~kg} \mathrm{BW}$ were assigned to one of four corn-soybean meal-based diets containing $0,200,400 \mathrm{or} 600 \mathrm{U} / \mathrm{kg}$ $\beta$-mannanase. Increasing the level of $\beta$-mannanase increased weight gain (quadratic effect; $\mathrm{p}<0.01$ ) and feed efficiency (linear and quadratic effect; $p<0.01$ ) during the second phase and the overall experiment. However, performance was unaffected ( $>0.05)$ by treatment during phase 1 . Increasing the amount of $\beta$-mannanase in the diet improved (linear and quadratic effect; $p<0.05$ ) the ATTD of $\mathrm{CP}, \mathrm{NDF}, \mathrm{ADF}$, calcium, and phosphorus during both phases. Based on the results of Exp. 1, the optimal supplementation level was determined to be $400 \mathrm{U} / \mathrm{kg}$ and this was the level that was applied in Exp. 2. In Exp. 2, 144 pigs weighing $23.50 \pm 1.86 \mathrm{~kg}$ BW were fed diets containing 0 or $400 \mathrm{U} / \mathrm{kg}$ of $\beta$-mannanase and 3,250 or $3,400 \mathrm{kcal} / \mathrm{kg}$ digestible energy (DE) in a $2 \times 2$ factorial design. $\beta$-Mannanase supplementation increased $(\mathrm{p}<0.01)$ weight gain and feed efficiency while the higher energy content increased $(\mathrm{p}<0.01)$ feed intake and feed efficiency during both phases and overall. Increased energy content and $\beta$-mannanase supplementation both increased ( $p<0.05)$ the ATTD of DM, CP, NDF, ADF, phosphorus, and GE during both phases. There were no significant interactions between energy level and $\beta$-mannanase for any performance or digestibility parameter. In conclusion, the $\beta$-mannanase used in the present experiment improved the performance of growing pigs fed diets based on corn and soybean. The mechanism through which the improvements were obtained appears to be related to improvements in ATTD. (Key Words: $\beta$-Mannanase, Growing Pigs, Performance, Digestibility, Soybean Meal)
\end{abstract}

\section{INTRODUCTION}

Soybean meal is by far the most popular protein source used for feeding livestock, accounting for almost $70 \%$ of all of the supplementary protein incorporated into animal feeds worldwide (Cromwell, 2012). Soybean meal is high in protein, has a good amino acid balance, is low in fiber and provides more energy than any other plant protein source (Waldroup, 2012).

Unfortunately, soybean meal contains approximately $22.7 \%$ of its carbohydrates in the form of non-starch polysaccharides (Jackson et al., 2004). These include acidic polysaccharides (8 to 10\%), arabinogalactins (5\%), cellulose (1 to $2 \%$ ) and approximately $1.3 \% \quad \beta$-mannans

\footnotetext{
* Corresponding Author: B. Dong. Tel: +86-10-6273-3588, Fax: +86-10-6273-3688, E-mail: dongb@mafic.ac.cn Submitted Nov. 2, 2012; Accepted Dec. 29, 2012; Revised Jan. 2, 2013
}

(Jackson et al., 2004). $\beta$-mannans are linear polysaccharides composed of repeating units of $\beta$-1,4-mannose and $\alpha-1,6-$ galactose and glucose units attached to the $\beta$-mannan backbone (Jackson et al., 2004). $\beta$-mannans cannot be digested by pigs because they lack the necessary enzymes targeting $\alpha$-1,6-galactosyl and $\beta-1-4-m a n n o s y l$ bonds (Veum and Odle, 2001).

Several research groups have attempted to improve the performance of growing-finishing pigs fed diets containing soybean meal by supplementing the diet with exogenous enzymes. These trials have typically involved the feeding of enzyme cocktails containing various combinations of enzymes including $\beta$-glucanase, xylanase, $\alpha$-galactosidase, pectinase and $\beta$-mannanse (Pettey et al., 2000; 2002; Kim et al., 2006; Wang et al., 2009; Ao et al., 2010). The response of growing-finishing pigs to these enzyme products has been variable. 
The application of genetic engineering in the process of enzyme production allows the development of enzymes targeted for specific purposes. During the past few years, numerous $\beta$-mannanase's have been purified and characterized from various organisms including bacteria, yeasts, fungi and plants (Cai et al., 2011). Our laboratory has expended a considerable amount of effort aimed at the development of $\beta$-mannanase's for the food, pulp, and paper and oil drilling industries (Chen et al., 2007;2008;2009; Li et al., 2010; Qiao et al., 2010; Cai et al., 2011).

We have recently developed a $\beta$-mannanase strain by molecular directed evolution which may have application in the feed industry (Cui, 2011). This enzyme is highly active over a broad acidic $\mathrm{pH}$ range (2.0 to 7.0 ), is thermostable to at least $60^{\circ} \mathrm{C}$, is resistant to pepsin and trypsin and is viable under simulated gastric conditions (Cui, 2011). These properties suggest that the enzyme could function in the harsh environment of the monogastric gastrointestinal tract (Chen et al., 2007). The current study was conducted to investigate the effects of this $\beta$-mannanase in corn-soybean meal-based diets on performance and apparent total tract digestibility (ATTD) in growing pigs.

\section{MATERIAL AND METHODS}

\section{Preparation of $\boldsymbol{\beta}$-mannanase}

Error-prone polymerase chain reaction (PCR) was carried out using a $\beta$-mannanase gene cloned from Aspergillus sulphureus as a template. The PCR products were first inserted into a pBGP1 vector and then transformed into Pichia pastoris X-33 by electroporation to construct a mutant library. Several mutants whose catalytic activities were enhanced compared with the wild type were obtained after two rounds of screening. Subsequently, the mutant with the highest activity was cultured in a $10 \mathrm{~L}$ fermenter. After $96 \mathrm{~h}$ of methanol induction, the modified $\beta$-mannanase reached $8,500 \mathrm{U} / \mathrm{ml}$ of catalytic activity, eight fold more than the wild type. Further details on the preparation of the enzyme can be obtained from Cui (2011).

The actual $\beta$-mannanase product used in this study was obtained by mixing $66 \%$ of the liquid fermentation broth produced above with $34 \%$ wheat bran and then air drying for $24 \mathrm{~h}$. This resulted in a $\beta$-mannanase preparation containing approximately 2,000,000 units (U) of $\beta$ mannanase per kg determined using the method of Chen et al. (2007). One unit of $\beta$-mannanase is defined as the amount of enzyme which liberates $1 \mu \mathrm{mol}$ of total reducing sugar (glucose equivalence) per $\mathrm{min}$ at the optimal enzymatic reaction conditions of $\mathrm{pH} 3.8$ and $65^{\circ} \mathrm{C}$.

The enzyme preparation was tested for contaminating levels of other enzymes using the dinitrosalicylic acid method of Chen et al. (2007). Briefly, $5 \mathrm{~g}$ of enzyme powder was dissolved in $50 \mathrm{ml} \mathrm{Na}_{2} \mathrm{HPO}_{4}$-citric acid buffer (pH 2.0) and left to sit for $30 \mathrm{~min}$ at room temperature. At the same time, $0.16 \mathrm{~g}$ of pure mannan, xylan, galactose and $\beta$-glucanase purchased from Sigma (St Louis, MO, USA) were dissolved in $20 \mathrm{ml}$ of $\mathrm{Na}_{2} \mathrm{HPO}_{4}$-citric acid buffer ( $\mathrm{pH}$ 2.0). Equal amounts $(400 \mu \mathrm{l})$ of the enzyme and substrate solutions were mixed into a $5 \mathrm{ml}$ test tube and incubated at $65^{\circ} \mathrm{C}$ for $20 \mathrm{~min}$. At the end of the incubation, $1 \mathrm{ml}$ of 3,5dinitrosalicylic acid solution was added to end the reaction. The samples were then boiled for $5 \mathrm{~min}$, allowed to cool and then made up to a constant volume of $5 \mathrm{ml}$ with water. The optical density of the solution was read on a spectrophotometer (Beijing PuxiGeneral TU-1901, Beijing, China) at $540 \mathrm{~nm}$ and the enzyme activity was calculated from a standard curve. No xylanase, $\beta$-glucanase or $\alpha$ galactosidase activity was detected in the enzyme preparation.

\section{Animal and facilities}

The animal performance study was conducted at China Agricultural University (Beijing, China) and the protocols used were approved by the Institutional Animal Care and Use Committee of China Agricultural University (Beijing, China). A total of 288 crossbred (Duroc $\times$ Landrace $\times$ Yorkshire) growing pigs were used in two experiments to investigate the effects of adding $\beta$-mannanase to cornsoybean meal-based diets on pig performance and ATTD. Both experiments lasted $28 \mathrm{~d}$ and were split into two phases namely 1 to $14 \mathrm{~d}$ (phase 1 ) and 15 to $28 \mathrm{~d}$ (phase 2).

The pigs were housed in an all in-all out room in $2.6 \times 1.8 \times 0.9 \mathrm{~m}^{3}$ pens equipped with a self-feeder and a nipple drinker to allow ad libitum access to feed and water. The environment for both experiments was controlled with the barn temperature set between 17 and $23^{\circ} \mathrm{C}$.

\section{Pig performance}

In Exp. 1,144 pigs weighing $23.60 \pm 1.59 \mathrm{~kg}$ BW were assigned to one of four corn-soybean meal-based diets containing $0,200,400$ or $600 \mathrm{U} / \mathrm{kg} \beta$-mannanase. The pigs were allotted to treatments on the basis of body weight, sex and litter in a randomized complete block design. There were six replicate pens for each treatment with six pigs (three barrows and three gilts) per pen.

The experimental diets were formulated to contain 3400 $\mathrm{kcal} / \mathrm{kg}$ of DE, $18.0 \%$ of CP and $1.10 \%$ of total lysine (Table 1) and were fed in meal form. The content of all other nutrients met or exceeded the estimated nutrient requirements for pigs of the weight range used in this experiment (NRC, 1998).

In Exp. 2,144 pigs weighing $23.50 \pm 1.86 \mathrm{~kg}$ BW were fed diets containing 0 or $400 \mathrm{U} / \mathrm{kg}$ of $\beta$-mannanase and 3,250 or $3,400 \mathrm{kcal} / \mathrm{kg} \mathrm{DE}$ in a $2 \times 2$ factorial arrangement. 
Table 1. Ingredient composition and chemical analysis of diets fed to investigate the effects of graded levels of $\beta$-mannanase on performance and digestibility in growing pigs (Exp. 1)

\begin{tabular}{|c|c|c|c|c|}
\hline \multirow{2}{*}{ Item } & \multicolumn{4}{|c|}{ Enzyme (U/kg) } \\
\hline & 0 & 200 & 400 & 600 \\
\hline \multicolumn{5}{|l|}{ Ingredient (\% as fed) } \\
\hline Corn & 66.35 & 66.35 & 66.35 & 66.35 \\
\hline Soybean meal $(44 \% \mathrm{CP})$ & 22.60 & 22.60 & 22.60 & 22.60 \\
\hline Wheat bran & 5.01 & 5.00 & 4.99 & 4.98 \\
\hline Soybean oil & 1.53 & 1.53 & 1.53 & 1.53 \\
\hline Limestone & 0.67 & 0.67 & 0.67 & 0.67 \\
\hline Dicalcium phosphate & 1.60 & 1.60 & 1.60 & 1.60 \\
\hline Salt & 0.35 & 0.35 & 0.35 & 0.35 \\
\hline L-Lysine $\cdot \mathrm{HCl}(78 \%)$ & 0.28 & 0.28 & 0.28 & 0.28 \\
\hline Threonine & 0.05 & 0.05 & 0.05 & 0.05 \\
\hline Choline & 0.20 & 0.20 & 0.20 & 0.20 \\
\hline Antibiotic & 0.06 & 0.06 & 0.06 & 0.06 \\
\hline Chromic oxide & 0.30 & 0.30 & 0.30 & 0.30 \\
\hline Vitamin-mineral premix ${ }^{1}$ & 1.00 & 1.00 & 1.00 & 1.00 \\
\hline$\beta$-mannanase preparation ${ }^{2}$ & 0.00 & 0.01 & 0.02 & 0.03 \\
\hline \multicolumn{5}{|l|}{ Chemical composition (as fed) } \\
\hline Digestible energy $(\mathrm{kcal} / \mathrm{kg})^{3}$ & 3,400 & 3,400 & 3,400 & 3,400 \\
\hline Crude protein $(\%)^{4}$ & 18.99 & 18.71 & 18.67 & 18.92 \\
\hline Calcium $(\%)^{4}$ & 0.66 & 0.65 & 0.72 & 0.69 \\
\hline Total phosphorus $(\%)^{4}$ & 0.59 & 0.58 & 0.61 & 0.58 \\
\hline Lysine $(\%)^{4}$ & 1.11 & 1.07 & 1.06 & 1.09 \\
\hline Threonine $(\%)^{4}$ & 0.78 & 0.74 & 0.71 & 0.67 \\
\hline Tryptophan $(\%)^{4}$ & 0.19 & 0.18 & 0.18 & 0.18 \\
\hline Methionine $(\%)^{4}$ & 0.31 & 0.29 & 0.27 & 0.30 \\
\hline
\end{tabular}

${ }^{1}$ Premix provided the following per $\mathrm{kg}$ of complete diet for grower pigs: vitamin $\mathrm{A}, 6,000 \mathrm{IU}$; vitamin $\mathrm{D}_{3}, 2,400 \mathrm{IU}$; vitamin E, $21.6 \mathrm{IU}$; vitamin $\mathrm{K}_{3}$, 2 $\mathrm{mg}$; vitamin $\mathrm{B}_{1}, 0.96 \mathrm{mg}$; vitamin $\mathrm{B}_{2}, 5.2 \mathrm{mg}$; vitamin $\mathrm{B}_{6}, 2 \mathrm{mg}$; vitamin $\mathrm{B}_{12}, 12 \mu \mathrm{g}$; nicotinic acid, $22 \mathrm{mg}$; pantothenic acid, $11.2 \mathrm{mg}$; folic acid, $0.4 \mathrm{mg}$; biotin, $40 \mu \mathrm{g}$; choline chloride, $0.4 \mathrm{~g}$; Fe, $120 \mathrm{mg}$; Cu, $140 \mathrm{mg}$; Zn, $100 \mathrm{mg}$; Mn, 16 mg; I, 0.24 mg; Se, $0.4 \mathrm{mg}$; Ca, 7.2 g; P, 0.8 g; NaCl, 4.4 g.

${ }^{2}$ Enzyme supplement contained approximately 2,000,000 units of $\beta$-mannanase per $\mathrm{kg}$ which was produced by mixing fermentation broth with wheat bran.

${ }^{3}$ Values were calculated according to NRC (1998). ${ }^{4}$ Analyzed values.

The $\beta$-mannanase supplementation level was chosen based on the results of Exp. 1. Pigs were assigned to treatment based on body weight, sex and litter. The formulations and the analyzed composition of diets fed during the feeding trial are presented in Table 2. All nutrients and energy were supplied according to NRC (1998) standards for growing pigs. For both experiments, pigs and feeders were weighed every two week to determine weight gain, feed intake and feed efficiency.

\section{Apparent total tract digestibility (ATTD)}

For both experiments, $0.3 \%$ chromic oxide was added to each diet to serve as an indigestible marker in order to evaluate the effects of $\beta$-mannanase on ATTD. Feed samples for each treatment were collected from every batch of feed produced, pooled and mixed within treatment. Fresh fecal samples were taken from each pen on d 13 and 14 (phase 1) as well as on d 27 and 28 (phase 2) and frozen for later analysis. Fecal samples were collected at least six times a day from the floor of each pen. The fecal samples were pooled within pen and dried in a forced-air drying oven at $65^{\circ} \mathrm{C}$ for $72 \mathrm{~h}$, ground through a $1-\mathrm{mm}$ screen and thoroughly mixed.

The digestibility of various chemical constituents was determined using the indicator method as described by Fan and Sauer (2002). The equation used was as follows:

$$
\mathrm{ND}(\%)=1-((\mathrm{DC} \times \mathrm{FN}) /(\mathrm{FC} \times \mathrm{DN})) \times 100 \%
$$

Where, ND is the ATTD, DC stands for the content of $\mathrm{Cr}_{2} \mathrm{O}_{3}$ in the experimental diets (\%), FN represents the content of a chemical constituent in the feces (\%), FC is the content of $\mathrm{Cr}_{2} \mathrm{O}_{3}$ in the feces (\%), DN stands the content of a chemical constituent in the diet $(\%)$.

\section{Chemical analyses}

Feed and fecal samples were analyzed according to the methods of the Association of Official Analytical Chemists (AOAC, 2000). Analyses were conducted for moisture (AOAC method 930.15), CP (AOAC method 984.13), 
Table 2. Ingredient composition and chemical analysis of diets fed to determine the effects of level of digestible energy (DE) and $\beta$-mannanase on performance and digestibility in growing pigs (Exp. 2)

\begin{tabular}{|c|c|c|c|c|}
\hline \multirow{2}{*}{ Item } & \multicolumn{2}{|c|}{$3,250 \mathrm{kcal} / \mathrm{kg} \mathrm{DE}$} & \multicolumn{2}{|c|}{$3,400 \mathrm{kcal} / \mathrm{kg} \mathrm{DE}$} \\
\hline & $0 \mathrm{U} / \mathrm{kg} \beta$-Mannanase & $400 \mathrm{U} / \mathrm{kg} \beta$-Mannanase & $0 \mathrm{U} / \mathrm{kg} \beta$-Mannanase & $400 \mathrm{U} / \mathrm{kg} \beta$-Mannanase \\
\hline \multicolumn{5}{|l|}{ Ingredient (\% as fed) } \\
\hline Corn & 64.10 & 64.10 & 66.45 & 66.45 \\
\hline Soybean meal (44\% CP) & 20.26 & 20.26 & 22.50 & 22.50 \\
\hline Wheat bran & 11.22 & 11.20 & 5.00 & 4.98 \\
\hline Soybean oil & 0.00 & 0.00 & 1.53 & 1.53 \\
\hline Limestone & 0.80 & 0.80 & 0.68 & 0.68 \\
\hline Dicalcium phosphate & 1.40 & 1.40 & 1.60 & 1.60 \\
\hline Salt & 0.35 & 0.35 & 0.35 & 0.35 \\
\hline L-Lysine·HCl (78\%) & 0.27 & 0.27 & 0.28 & 0.28 \\
\hline Threonine & 0.04 & 0.04 & 0.05 & 0.05 \\
\hline Choline & 0.20 & 0.20 & 0.20 & 0.20 \\
\hline Antibiotic & 0.06 & 0.06 & 0.06 & 0.06 \\
\hline Chromium oxide & 0.30 & 0.30 & 0.30 & 0.30 \\
\hline Vitamin-mineral premix $^{1}$ & 1.00 & 1.00 & 1.00 & 1.00 \\
\hline$\beta$-Mannanase preparation ${ }^{2}$ & 0.00 & 0.02 & 0.00 & 0.02 \\
\hline \multicolumn{5}{|l|}{ Chemical composition (as fed) } \\
\hline Digestible energy $(\mathrm{kcal} / \mathrm{kg})^{3}$ & 3,250 & 3,250 & 3,400 & 3,400 \\
\hline Crude protein $(\%)^{4}$ & 17.79 & 17.97 & 18.78 & 18.63 \\
\hline Calcium $(\%)^{4}$ & 0.69 & 0.71 & 0.73 & 0.67 \\
\hline Total phosphorus $(\%)^{4}$ & 0.56 & 0.54 & 0.60 & 0.63 \\
\hline Lysine $(\%)^{4}$ & 0.98 & 0.95 & 1.10 & 1.07 \\
\hline Threonine $(\%)^{4}$ & 0.60 & 0.61 & 0.69 & 0.68 \\
\hline Tryptophan $(\%)^{4}$ & 0.18 & 0.19 & 0.19 & 0.19 \\
\hline Methionine $(\%)^{4}$ & 0.26 & 0.25 & 0.28 & 0.29 \\
\hline
\end{tabular}

${ }^{1}$ Premix provided the following per kg of complete diet: vitamin A, 6,000 IU; vitamin $\mathrm{D}_{3}, 2,400 \mathrm{IU}$; vitamin $\mathrm{E}, 21.6 \mathrm{IU}$; vitamin $\mathrm{K}_{3}, 2 \mathrm{mg}$; vitamin $\mathrm{B}_{1}$, $0.96 \mathrm{mg}$; vitamin $\mathrm{B}_{2}, 5.2 \mathrm{mg}$; vitamin $\mathrm{B}_{6}, 2 \mathrm{mg}$; vitamin $\mathrm{B}_{12}, 12 \mu \mathrm{g}$; nicotinic acid, $22 \mathrm{mg}$; pantothenic acid, $11.2 \mathrm{mg}$; folic acid, $0.4 \mathrm{mg}$; biotin, $40 \mu \mathrm{g}$; choline chloride, $0.4 \mathrm{~g}$; Fe, $120 \mathrm{mg}$; Cu, $140 \mathrm{mg}$; Zn, $100 \mathrm{mg}$; Mn, $16 \mathrm{mg}$; I, $0.24 \mathrm{mg}$; Se, $0.4 \mathrm{mg}$; Ca, $7.2 \mathrm{~g} ; \mathrm{P}, 0.8 \mathrm{~g} ; \mathrm{NaCl}, 4.4 \mathrm{~g}$.

${ }^{2}$ Enzyme supplement contained approximately 2,000,000 units of $\beta$-mannanase per $\mathrm{kg}$ which was produced by mixing fermentation broth with wheat bran.

${ }^{3}$ Values were calculated according to NRC (1998). ${ }^{4}$ Analyzed values.

calcium (AOAC method 968.08) and phosphorus (AOAC method 965.17). NDF and ADF were determined using fiber bags and fiber analyzer equipment (Fiber Analyzer, Ankom Technology, Macedon, NY, USA) following an adaptation procedure described by Van Soest et al. (1991). GE was measured via an adiabatic oxygen bomb calorimeter (Parr Instruments, Moline, IL, USA). The chromium concentrations of diets and fecal samples were determined after nitric acid-perchloric acid wet ash sample preparation using a Polarized Zeeman Atomic Absorption Spectrometer (Hitachi Z2000, Tokyo, Japan).

Feed and feces were hydrolyzed with $6 \mathrm{~N} \mathrm{HCl}$ at $110^{\circ} \mathrm{C}$ for $24 \mathrm{~h}$ and analyzed for amino acids using an Amino Acid Analyzer (Hitachi L-8900, Tokyo, Japan). Methionine and cystine were determined as methionine sulfone and cysteic acid after cold performic acid oxidation overnight and hydrolyzing with $7.5 \mathrm{~N} \mathrm{HCl}$ at $110^{\circ} \mathrm{C}$ for $24 \mathrm{~h}$ using an Amino Acid Analyzer (Hitachi L-8800, Tokyo, Japan). Tryptophan was determined after $\mathrm{LiOH}$ hydrolysis for $22 \mathrm{~h}$ at $110^{\circ} \mathrm{C}$ using High Performance Liquid Chromatography (Agilent 1200 Series, Santa Clara, CA, USA). All analyses were performed in duplicate and repeated when the results differed by more than $5 \%$.

\section{Statistical analyses}

For all of the statistical analysis for these experiments, the pen served as the experimental unit. In Exp. 1, statistical analysis was conducted using the GLM procedure (SAS Inst. Inc., Cary, NC, USA) as a randomized complete block design. Linear and quadratic comparisons were conducted to evaluate the effects of increasing $\beta$-mannanase supplementation. In Exp. 2, data were analyzed as a $2 \times 2$ factorial arrangement. The main effects of energy, $\beta$-mannanase, and their interaction were determined by the PROC MIXED procedure of SAS. Statistical significance was declared at $\mathrm{p}<0.05$, whereas a trend was expressed when $p<0.10$. Results are presented as least square means. 
Table 3. Performance of growing pigs fed diets containing graded levels of $\beta$-mannanase (Exp. 1$)^{1}$

\begin{tabular}{|c|c|c|c|c|c|c|c|c|}
\hline & \multicolumn{4}{|c|}{$\beta$-mannanase (U/kg) } & \multirow{2}{*}{$\mathrm{SEM}^{2}$} & \multicolumn{3}{|c|}{ p-value } \\
\hline & 0 & 200 & 400 & 600 & & ANOVA & Linear & Quadratic \\
\hline \multicolumn{9}{|l|}{ Day 1 to 14} \\
\hline Weight gain $(\mathrm{g} / \mathrm{d})$ & 637 & 668 & 690 & 669 & 40.5 & 0.83 & 0.50 & 0.69 \\
\hline Feed intake (g/d) & 1,509 & 1,467 & 1,474 & 1,428 & 52.1 & 0.75 & 0.30 & 0.59 \\
\hline Feed efficiency & 427 & 455 & 469 & 466 & 24.6 & 0.62 & 0.23 & 0.40 \\
\hline \multicolumn{9}{|l|}{ Day 15 to 28} \\
\hline Weight gain $(\mathrm{g} / \mathrm{d})$ & 708 & 862 & 904 & 836 & 43.4 & 0.03 & 0.06 & $<0.01$ \\
\hline Feed intake (g/d) & 1,818 & 1,754 & 1,761 & 1,732 & 49.4 & 0.65 & 0.25 & 0.49 \\
\hline Feed efficiency & 389 & 489 & 516 & 482 & 18.3 & $<0.01$ & $<0.01$ & $<0.01$ \\
\hline \multicolumn{9}{|l|}{ Day 1 to 28} \\
\hline Weight gain $(\mathrm{g} / \mathrm{d})$ & 665 & 759 & 793 & 749 & 31.1 & 0.05 & 0.08 & 0.01 \\
\hline Feed intake (g/d) & 1,664 & 1,626 & 1,617 & 1,580 & 45.0 & 0.63 & 0.19 & 0.44 \\
\hline Feed efficiency & 404 & 466 & 491 & 474 & 14.1 & $<0.01$ & $<0.01$ & $<0.01$ \\
\hline
\end{tabular}

${ }^{1}$ Values represent the means of six pens with six pigs per pen. ${ }^{2} \mathrm{SEM}=$ Standard error of the mean.

\section{RESULTS}

\section{Exp. 1}

Increasing the level of $\beta$-mannanase in the diet increased weight gain (quadratic effect; $\mathrm{p}<0.01$ ) and feed efficiency (linear and quadratic effect; $\mathrm{p}<0.01$ ) during the second phase and for the overall experiment (Table 3). However, performance was unaffected by treatment during phase 1.

Increasing the amount of $\beta$-mannanase in the diet improved $(\mathrm{p}<0.05)$ the ATTD of DM, CP, NDF, calcium, and phosphorus during both periods (Table 4). Based on the results of Exp. 1, the optimal supplementation level was determined to be $400 \mathrm{U} / \mathrm{kg}$ and this was the level that was applied in Exp. 2.
Exp. 2

$\beta$-Mannanase supplementation increased $(p<0.01)$ weight gain and feed efficiency while the higher energy content increased $(\mathrm{p}<0.01)$ feed intake and feed efficiency during both phases and overall (Table 5). Increased energy content and $\beta$-mannanase supplementation both increased $(\mathrm{p}<0.05)$ the ATTD of DM, CP, NDF, ADF, phosphorus, and GE during both phases (Table 6). There were no significant interactions between energy level and $\beta$-mannanase for any performance or digestibility parameters.

\section{DISCUSSION}

Several researchers have attempted to improve the performance of growing-finishing pigs fed diets containing soybean meal by adding exogenous enzymes to the diet.

Table 4. Effect of graded levels of $\beta$-mannanase supplementation on apparent total tract digestibility (Exp. 1) ${ }^{1}$

\begin{tabular}{|c|c|c|c|c|c|c|c|c|}
\hline \multirow{2}{*}{ Digestibility (\%) } & \multicolumn{4}{|c|}{$\beta$-mannanase (U/kg) } & \multirow{2}{*}{$\mathrm{SEM}^{2}$} & \multicolumn{3}{|c|}{ p-value } \\
\hline & 0 & 200 & 400 & 600 & & ANOVA & Linear & Quadratic \\
\hline \multicolumn{9}{|l|}{ Day 13 and 14} \\
\hline Dry matter & 78.80 & 78.81 & 82.62 & 81.72 & 0.71 & $<0.01$ & $<0.01$ & 0.01 \\
\hline Gross energy & 79.52 & 77.62 & 82.78 & 81.36 & 0.72 & $<0.01$ & 0.02 & 0.07 \\
\hline Crude protein & 67.73 & 68.09 & 73.78 & 73.04 & 0.98 & $<0.01$ & $<0.01$ & $<0.01$ \\
\hline Neutral detergent fiber & 50.93 & 55.72 & 60.97 & 56.51 & 2.19 & 0.03 & 0.05 & 0.02 \\
\hline Acid detergent fiber & 47.26 & 51.96 & 58.19 & 52.49 & 2.29 & 0.03 & 0.07 & 0.02 \\
\hline Calcium & 37.12 & 49.23 & 43.51 & 50.55 & 2.17 & $<0.01$ & 0.01 & 0.02 \\
\hline Phosphorus & 34.65 & 39.44 & 47.60 & 47.68 & 3.64 & 0.05 & 0.01 & 0.02 \\
\hline \multicolumn{9}{|l|}{ Day 27 and 28} \\
\hline Dry matter & 80.35 & 81.20 & 83.56 & 82.84 & 0.70 & 0.02 & $<0.01$ & 0.07 \\
\hline Gross energy & 80.90 & 81.26 & 85.74 & 81.76 & 0.83 & $<0.01$ & 0.17 & 0.06 \\
\hline Crude protein & 72.38 & 72.97 & 77.63 & 75.68 & 1.13 & 0.01 & 0.01 & 0.03 \\
\hline Neutral detergent fiber & 48.51 & 59.36 & 59.66 & 58.02 & 1.85 & $<0.01$ & 0.01 & $<0.01$ \\
\hline Acid detergent fiber & 49.91 & 56.39 & 58.64 & 57.18 & 2.20 & 0.05 & 0.03 & 0.02 \\
\hline Calcium & 37.86 & 46.96 & 48.39 & 45.32 & 1.67 & $<0.01$ & 0.02 & $<0.01$ \\
\hline Phosphorus & 43.26 & 47.49 & 50.25 & 48.25 & 1.63 & 0.04 & 0.03 & 0.02 \\
\hline
\end{tabular}

\footnotetext{
${ }^{1}$ Value represent the means of six pens with six pigs per pen. ${ }^{2} \mathrm{SEM}=$ Standard error of the mean.
} 
Table 5. Effect of energy level and $\beta$-mannanase supplementation on the performance of growing pigs (Exp. 2) ${ }^{1}$

\begin{tabular}{|c|c|c|c|c|c|c|c|c|}
\hline & \multicolumn{2}{|c|}{$3,250 \mathrm{kcal} / \mathrm{kg} \mathrm{DE}$} & \multicolumn{2}{|c|}{$3,400 \mathrm{kcal} / \mathrm{kg} \mathrm{DE}$} & \multirow[b]{2}{*}{ SEM $^{2}$} & \multicolumn{3}{|c|}{ p-value } \\
\hline & $\begin{array}{c}0 \mathrm{U} / \mathrm{kg} \\
\text { mannanase }\end{array}$ & $\begin{array}{c}400 \mathrm{U} / \mathrm{kg} \\
\text { mannanase }\end{array}$ & $\begin{array}{c}0 \mathrm{U} / \mathrm{kg} \\
\text { mannanase }\end{array}$ & $\begin{array}{c}400 \mathrm{U} / \mathrm{kg} \\
\text { mannanase }\end{array}$ & & Energy & Enzyme & Interaction \\
\hline \multicolumn{9}{|l|}{ Day 1 to 14} \\
\hline Weight gain $(\mathrm{g} / \mathrm{d})$ & 623 & 696 & 637 & 690 & 29.87 & 0.88 & 0.05 & 0.74 \\
\hline Feed intake (g/d) & 1677 & 1631 & 1,509 & 1,474 & 51.96 & $<0.01$ & 0.45 & 0.92 \\
\hline Feed efficiency & 372 & 428 & 427 & 469 & 22.87 & 0.05 & 0.05 & 0.75 \\
\hline \multicolumn{9}{|l|}{ Day 15 to 28} \\
\hline Weight gain $(\mathrm{g} / \mathrm{d})$ & 668 & 826 & 708 & 905 & 40.51 & 0.16 & $<0.01$ & 0.63 \\
\hline Feed intake (g/d) & 1,995 & 1,963 & 1,850 & 1,690 & 23.93 & $<0.01$ & 0.10 & 0.27 \\
\hline Feed efficiency & 334 & 424 & 383 & 516 & 26.04 & 0.01 & $<0.01$ & 0.37 \\
\hline \multicolumn{9}{|l|}{ Day 1 to 28} \\
\hline Weight gain $(\mathrm{g} / \mathrm{d})$ & 645 & 761 & 672 & 798 & 27.56 & 0.26 & $<0.01$ & 0.86 \\
\hline Feed intake $(\mathrm{g} / \mathrm{d})$ & 1,836 & 1,798 & 1,679 & 1,582 & 41.13 & $<0.01$ & 0.11 & 0.49 \\
\hline Feed efficiency & 353 & 424 & 401 & 505 & 18.12 & $<0.01$ & $<0.01$ & 0.38 \\
\hline
\end{tabular}

${ }^{1}$ Value represent means of six pens with six pigs per pen. ${ }^{2} \mathrm{SEM}=$ Standard error of the mean.

These trials have typically involved the feeding of enzyme cocktails containing various combinations of enzymes including xylanase, $\beta$-glucanase, $\alpha$-galactosidase, pectinase, and $\beta$-mannanase (Pettey et al., 2000; 2002; Kim et al., 2006; Wang et al., 2009; Ao et al., 2010). The response of growing-finishing pigs to these enzyme products has varied.

In the present trial, a modified source of $\beta$-mannanase was applied. The enzyme preparation was approximately $97 \% \beta$-mannanase and, as determined in the present trial, was devoid of xylanase, $\beta$-glucanase and $\alpha$-galactosidase activity. The enzyme was produced using a $\beta$-mannanase gene cloned from the fungus Aspergillus sulphureus as a template. The PCR products were first inserted into a pBGP1 vector and then transformed into Pichia pastoris X-
33 by electroporation. The yeast Pichia pastoris is a favored system for expressing heterologous proteins due to its many advantages such as protein processing, protein folding and post translational modification (Chen et al., 2007). Most importantly, the yeast can be grown in inexpensive media (Chen et al., 2007).

Most fungal $\beta$-mannanases have a $\mathrm{pH}$ optima of 2.4 to 6.0 , and this acidic $\mathrm{pH}$ range makes fungal $\beta$-mannanases promising candidates for use in the animal feed industry (Cai et al., 2011). In addition, we have previously reported that the $\beta$-mannanase strain used in the present study possesses several other properties which may make it ideally suited for in vivo use (Cui, 2011). This enzyme is thermostable to at least $60^{\circ} \mathrm{C}$, is resistant to pepsin and

Table 6. Effect of energy level and $\beta$-mannanase supplementation on apparent total tract digestibility (Exp. 2$)^{1}$

\begin{tabular}{|c|c|c|c|c|c|c|c|c|}
\hline & \multicolumn{2}{|c|}{$3,250 \mathrm{kcal} / \mathrm{kg} \mathrm{DE}$} & \multicolumn{2}{|c|}{$3,400 \mathrm{kcal} / \mathrm{kg} \mathrm{DE}$} & \multirow[b]{2}{*}{ SEM $^{2}$} & \multicolumn{3}{|c|}{$\mathrm{p}$-value } \\
\hline & $\begin{array}{c}0 \mathrm{U} / \mathrm{kg} \\
\text { mannanase }\end{array}$ & $\begin{array}{c}400 \mathrm{U} / \mathrm{kg} \\
\text { mannanase }\end{array}$ & $\begin{array}{c}0 \mathrm{U} / \mathrm{kg} \\
\text { mannanase }\end{array}$ & $\begin{array}{c}400 \mathrm{U} / \mathrm{kg} \\
\text { mannanase }\end{array}$ & & Energy & Enzyme & Interaction \\
\hline \multicolumn{9}{|l|}{ Day 13 and 14} \\
\hline Dry matter & 77.39 & 79.42 & 78.80 & 82.62 & 0.49 & $<0.01$ & $<0.01$ & 0.09 \\
\hline Crude protein & 66.64 & 69.95 & 67.73 & 73.78 & 0.96 & 0.02 & $<0.01$ & 0.17 \\
\hline Neutral detergent fiber & 44.94 & 57.83 & 53.43 & 56.98 & 1.89 & 0.04 & $<0.01$ & 0.07 \\
\hline Acid detergent fiber & 45.16 & 54.18 & 53.93 & 57.86 & 2.13 & 0.01 & 0.01 & 0.24 \\
\hline Calcium & 37.75 & 43.94 & 37.12 & 43.52 & 2.81 & 0.84 & 0.03 & 0.97 \\
\hline Phosphorus & 37.88 & 42.26 & 41.15 & 48.60 & 1.75 & 0.01 & $<0.01$ & 0.38 \\
\hline Gross energy & 77.62 & 78.56 & 79.52 & 82.78 & 0.63 & $<0.01$ & $<0.01$ & 0.08 \\
\hline \multicolumn{9}{|l|}{ Day 27 and 28} \\
\hline Dry matter & 77.51 & 79.10 & 79.35 & 82.90 & 0.92 & 0.01 & 0.01 & 0.30 \\
\hline Crude protein & 70.15 & 72.63 & 72.72 & 77.63 & 1.73 & 0.04 & 0.05 & 0.49 \\
\hline Neutral detergent fiber & 52.37 & 57.32 & 56.84 & 62.82 & 2.02 & 0.01 & $<0.01$ & 0.73 \\
\hline Acid detergent fiber & 48.18 & 53.38 & 53.24 & 57.97 & 2.24 & 0.03 & 0.02 & 0.75 \\
\hline Calcium & 37.85 & 43.48 & 39.53 & 47.21 & 2.01 & 0.19 & 0.01 & 0.96 \\
\hline Phosphorus & 42.18 & 43.59 & 44.09 & 47.41 & 1.05 & 0.01 & 0.03 & 0.37 \\
\hline Gross energy & 77.66 & 79.46 & 80.23 & 83.27 & 0.96 & $<0.01$ & 0.02 & 0.53 \\
\hline
\end{tabular}

${ }^{1}$ Value represent means of six pens with six pigs per pen. ${ }^{2} \mathrm{SEM}=$ Standard error of the mean. 
trypsin and has been shown to be viable under simulated gastric conditions (Cui, 2011).

In Exp.1, graded levels (0, 200, 400 and $600 \mathrm{U} / \mathrm{kg})$ of $\beta$-mannanase were fed to the growing pigs and both weight gain and feed efficiency were quadratically affected by $\beta$-mannanase inclusion. The optimum inclusion level appeared to be $400 \mathrm{U} / \mathrm{kg}$ and at that level, weight gain was increased $16.1 \%$ and feed efficiency was improved $17.7 \%$ compared with the unsupplemented diet.

The magnitude of the improvement in pig performance obtained in the present experiment is notably greater than which has been previously reported for experiments involving $\beta$-mannanase supplementation of grower-finisher pig diets. For example, Pettey et al. (2002) reported that weight gain was only increased $3.4 \%$ and feed efficiency $3.9 \%$ in their experiment in which growing-finishing pigs were fed diets supplemented with $\beta$-mannanase. Furthermore, Ao et al. (2010) reported improvements of $4.4 \%$ and $6.3 \%$ for weight gain and feed efficiency with one enzyme product while a second product produced no improvements in weight gain and feed efficiency. The differences in the magnitude of the response to enzyme supplementation in the current experiment and previous results could be due to differences in enzyme purity, level of supplementation, thermostability and the $\mathrm{pH}$ optimum of the various products used.

The improvement in performance due to enzyme supplementation in the current study appeared to be related to improvements in the ATTD of various chemical constituents as increasing the amount of $\beta$-mannanase in the diet improved the ATTD of DM, CP, NDF, calcium, and phosphorus. Kim et al. (2006), Wang et al. (2009), and Ao et al. (2010) also reported increases in digestibility as a result of $\beta$-mannanase supplementation. In contrast, Pettey et al. (2002) reported no change in nutrient digestibility as a result of $\beta$-mannanase supplementation.

The magnitude of the improvements in digestibility ranged from approximately 3 to over 10 percentage units for some chemical constituents indicating that the $\beta$-mannanase preparation is not simply acting on the $1.3 \%$ $\beta$-mannans found in soybean meal (Jackson et al., 2004) and breaking down this polymer to its constituent monosaccharides. If this was the case, it would be impossible to get improvements in digestibility greater than $1.3 \%$. Therefore, the increases in digestibility coefficients observed must occur through other mechanisms.

Soluble non-starch polysaccharides such as $\beta$-mannans may increase intestinal viscosity (Choct et al., 2010). An increase in digesta viscosity may interfere with the digestive process by impeding enzyme-substrate association or by reducing the rate at which released nutrients approach the mucosal surface for absorption (Thacker et al., 1991). The increase in digestibility of such a variety of chemical constituents ranging from minerals such as calcium and phosphorus to $\mathrm{CP}$ and GE suggests that $\beta$-mannanase increases digestibility through a fairly unspecific mechanism such as by reducing digesta viscosity.

Another possible mechanism through which $\beta$-mannanase may contribute to improvements in digestibility when they occur is through an increase in digestive enzyme activity. We previously reported that $\beta$-mannanase increased amylase and trypsin activity in the digesta of broilers (Li et al., 2010) and if a similar increase occurs in the digesta of swine fed diets supplemented with $\beta$-mannanase, it could explain, at least partially, the improvements in CP, GE and DM digestibility noted. However, changes in these specific enzyme activities would not explain the improvements in fiber and mineral digestibility noted.

The results of Exp. 1 clearly demonstrate a quadratic effect of $\beta$-mannanase on both pig performance and digestibility. For both performance and digestibility data, improvements were noted as the dietary inclusion level increased up to $400 \mathrm{U} / \mathrm{kg}$, whereupon inclusion of additional quantities of $\beta$-mannanase produced no further enhancement effects and in fact appeared to cause performance and digestibility to decline. Ao et al. (2010) reported a similar effect as supplementation with $0.1 \%$ enzyme improved pig performance while supplementation with $0.2 \%$ enzyme did not produce any additional benefit. In addition, Kim et al. (2006) reported that $0.05 \%$ carbohydrase improved nutrient digestibility while supplementation with $0.1 \%$ carbohydrase resulted in lower nutrient digestibility than supplementation with $0.05 \%$. An explanation for the failure of additional quantities of enzyme to produce additional benefits is not readily apparent but definitely this is not a case of "if a little is good, more is better" and there appears to be an optimum level for enzyme supplementation and choice of this level needs to be given careful consideration.

Based on the results of Exp. 1, the optimum $\beta$-mannanase inclusion level was determined to be 400 $\mathrm{U} / \mathrm{kg}$ as this level appeared to optimize both pig performance and digestibility. Interestingly, Yoon et al. (2010) also reported that $400 \mathrm{U} / \mathrm{kg}$ was the optimum inclusion level for $\beta$-mannanase in diets containing 10 and $15 \%$ corn distillers dried grains with solubles fed to grower and finisher pigs.

Previous studies have shown that pigs fed a diet with a decreased DE content but supplemented with $\beta$-mannanase had similar average daily gain and feed efficiency compared with pigs fed a normal energy diet without $\beta$-mannanase supplementation (Pettey et al., 2002). Therefore, Exp. 2 was conducted to investigate whether enzyme supplementation 
at the optimum inclusion level of $400 \mathrm{U} / \mathrm{kg}$ could improve the performance of pigs fed lower energy diets.

In Exp. 2, the weight gain and feed efficiency of the pigs fed the low energy diet supplemented with $400 \mathrm{U} / \mathrm{kg}$ of $\beta$-mannanase was equal to or better than that of pigs fed the unsupplemented high energy diet during all phases of production. Although the DE of the low energy diet was $3,250 \mathrm{kcal} / \mathrm{kg}$, which was $150 \mathrm{kcal} / \mathrm{kg}$ lower than that of control diet $(3,400 \mathrm{kcal} / \mathrm{kg})$, pigs fed the low energy diet had similar performance as pigs fed the normal energy diet. This indicates that the amount of additionally available DE due to supplementation with $\beta$-mannanase is at least 150 $\mathrm{kcal} / \mathrm{kg}$. Similar to the results of Exp. 1, the improvements in pig performance appeared to be mediated through improvements in digestibility.

\section{CONCLUSIONS}

The $\beta$-mannanase used in the present experiment significantly improved the performance of growing pigs fed diets based on corn and soybean. The mechanism through which the improvements were obtained appeared to be related to improvements in digestibility. The magnitude of the improvements in pig performance and digestibility obtained in the present experiment were notably greater than has been previously reported for experiments involving $\beta$-mannanase supplementation of grower-finisher pig diets. It is believed that the application of genetic engineering to develop an enzyme specifically targeted for in vivo use explains the enhanced results.

\section{ACKNOWLEDGEMENTS}

This work was supported by the National Natural Science Foundation of PR China (No.31072061), the Scientific and Technical Supporting Programs (2011BAD26B02, 2013BAD10B01) and the National High Technology Research and Development Program (2012AA022208).

\section{REFERENCES}

AOAC. 2000. Official methods of analysis. $17^{\text {th }}$ ed. Association of Official Analytical Chemists, Arlington, VA, USA.

Ao, X., Q. W. Meng, L. Yan, H. J. Kim, S. M. Hong, J. H. Cho and I. H. Kim. 2010. Effects of non-starch polysaccharidedegrading enzymes on nutrient digestibility, growth performance and blood profiles of growing pigs fed a diet based on corn and soybean meal. Asian-Aust. J. Anim. Sci. 23:1632-1638.

Cai, H., P. Shi, H. Luo, Y, Bai, H. Huang, P. Yang and B. Yao. 2011. Acidic $\beta$-mannanase from Penicillium pinophilum $\mathrm{C} 1$ : Cloning, characterization and assessment of its potential for animal feed application. J. Biosci. Bioeng. 112:551-557.
Chen, X., Y. Cao, Y. Ding, W. Lu and D. Li. 2007. Cloning functional expression and characterization of Aspergillus sulphureus $\beta$-mannanase in Pichia pastoris. J. Biotechnol. 128:452-461.

Chen, X., W. Lu, Y. Cao and D. Li. 2008. Prokaryotic expression, purification and characteization of Aspergillus sulphureus $\beta$ mannanase and site directed mutagenesis of the catalytic residues. Appl. Biochem. Biotechnol. 149:139-144.

Chen, X., J. Qiao, H. Yu and Y. Cao. 2009. Overexpression of an optimized Aspergillus sulphureus $\beta$-mannanase gene in Pichia pastoris. Biologia 64:235-238.

Choct, M., Y. Dersjant-Li, J. McLeish and M. Peisker. 2010. Soy oligosaccharides and soluble non-starch polysaccharides: A review of digestion, nutritive and anti-nutritive effects in pigs and poultry. Asian-Aust. J. Anim. Sci. 23:1386-1398.

Crowell, G. L. 2012. Soybean meal: An exceptional protein source. Soybean Meal InfoCenter, Ankeny, IA. Available at www.soymeal.org/factsheets/.

Cui, X. 2011. Molecular directed evolution and overexpression of $\beta$-mannanase. Masters. Thesis, China Agricultual University, Beijing, China. p. 65.

Fan, M. Z. and W. C. Sauer. 2002. Determination of true ileal amino acid digestibility and the endogenous amino acid outputs associated with barley samples for growing-finishing pigs by the regression analysis technique. J. Anim. Sci. 80:1593-1605.

Jackson, M. E., K. Geronian, A. Knox, J. McNab and E. McCartney. 2004. A dose response study with the feed enzyme $\beta$-mannanase in broilers provided with corn-soybean meal based diets in the absence of antibiotic growth promoters. Poult. Sci. 83:1992-1996.

Kim, S. W., J. H. Zhang, K. T. Soltwedel and D. A. Knabe. 2006. Use of carbohydrases in corn-soybean meal based growerfinisher pig diets. Anim. Res. 55:563-578.

Li, Y., X. Chen, Y. Chen, Z. Li and Y. Cao. 2010. Effects of $\beta$-mannanase expressed by Pichia pastoris in corn-soybean meal diets on broiler performance, nutrient digestibility, energy utilization and immunoglobulin levels. Anim. Feed Sci. Technol. 159:59-67.

NRC. 1998. Nutrient Requirements of Swine 10th rev. ed. National Academy Press, Washington DC, USA.

Pettey, L. A., S. D. Carter, B. W. Senne and J. A. Shriver. 2000. Effects of hemicell ${ }^{\circledR}$ addition to corn-soybean meal diets on growth performance, carcass traits, and apparent nutrient digestibility in growing-finishing pigs. J. Anim. Sci. 78:111116.

Pettey, L. A., S. D. Carter, B. W. Senne and J. A. Shriver. 2002. Effect of beta-mannanase adding to corn-soybean meal diets on growth performance, carcass traits, and nutrient digestibility of weanling and growing-finishing pigs. J. Anim. Sci. 80:1012-1019.

Qiao, J., Z. Rao, B. Dong and Y. Cao. 2010. Expression of Bacillus subtilis MA139 $\beta$-mannanase in Pichia pastoris and the enzyme characterization. Appl. Biochem. Biotechnol. 160:1362-1370.

Thacker, P. A., G. L. Campbell and J. Grootwassink. 1991. The effect of organic acids and enzyme supplementation on the performance of pigs fed barley-based diets. Can. J. Anim. Sci. 72:395-402. 
Van Soest, P. J., J. B. Robertson and B. A. Lewis. 1991. Methods for dietary fiber, neutral detergent fiber, and nonstarch polysaccharides in relation to animal nutrition. J. Dairy Sci. 74:3583-3597.

Veum, T. L. and J. Odle. 2001. Feeding neonatal pigs. Page 675694 in Swine Nutrition. 2nd ed. (Ed. A. J. Lewis and L.L. Southern). CRC Press, New York.

Waldroup, P. W. 2012. Soybean meal: Demand. Soybean Meal InfoCenter, Ankeny, IA. Available at www.soymeal.org/ factsheets/.
Wang, J. P., S. M. Hong, L. Yan, J. S. Yoo, J. H. Lee, H. D. Jang, H. J. Kim and I. H. Kim. 2009. Effects of single or carbohydrases cocktail in low-nutrient-density diets on growth performance, nutrient digestibility, blood characteristics and carcass traits in growing-finishing pigs. Livest. Sci. 126:215-220.

Yoon, S. Y., Y. X. Yang, P. L. Shinde, J. Y. Choi, J. S. Kim, Y. W. Kim, K. Yun, J. K. Jo, J. H. Lee, S. J. Ohh, I. K. Kwon and B. J. Chae. 2010. Effects of mannanase and distillers dried grain with solubles on growth performance, nutrient digestibility, and carcass characteristics of grower-finisher pigs. J. Anim. Sci. 88:181-191. 